African Crop Science Journal by African Crop Science Society is licensed under a Creative Commons Attribution 3.0 Uganda License. Based on a work at www.ajol.info/ and www.bioline.org.br/cs DOI: https://dx.doi.org/10.4314/acsj.v27i4.1

\title{
SUITABILITY OF POTATO VARIETIES GROWN FROM TRUE SEED AND SEED TUBERS FOR CHIPS MAKING USING A MICROWAVE OVEN
}

\author{
T. TAUFIQUEE ${ }^{1,2}$, T.S. ROY 2 , R. CHAKRABORTY², M. MOSTOFA ${ }^{3}$, B.C. KUNDU ${ }^{4}$, \\ H.K.M. DELOWAR ${ }^{5}$ and F. NOWROZ ${ }^{2}$
}
'Department of Bioproduction, Faculty of Agriculture, Yamagata University, 1-23 Wakaba Machi, Tsuruoka 997-8555, Yamagata, Japan
${ }^{2}$ Department of Agronomy, Faculty of Agriculture, Sher-e-Bangla Agricultural University, Dhaka-1207, Bangladesh
${ }^{3}$ Institute of Seed Technology, Sher-e-Bangla Agricultural University, Dhaka-1207, Bangladesh
${ }^{4}$ Tuber Crops Research Centre, Bangladesh Agricultural Research Institute, Gazipur-1701, Bangladesh
${ }^{5}$ Department of Environmental Science and Technology, Jashore University of Science and Technology, Jashore-7408, Bangladesh
Corresponding author: marufsau@ @otmail.com

(Received 12 March 2019; accepted 21 October 2019)

\begin{abstract}
One of the basic concepts of microwave drying of potato (Solanum tuberosum) chips is to achieve desired chip colour and texture, within a short period. In this study, chips (1 mm thickness) of true potato seed (TPS) ('BARI TPS-1') and seed potato ('Asterix') varieties were heated for 0, 10, 20, 30, 60, $90,120,180$ and $300 \mathrm{~s}$ by a microwave oven, and the changes in chips were analysed physiologically and histologically to investigate the suitability of TPS tubers as processing potato. Although potato chip crispiness of both potato varieties increased continuously throughout the heating treatment, crispiness of 'BARI TPS-1', increased more slowly than that of 'Asterix', indicating that TPS chips became less rigid and fluffy after microwave heating than that of 'Asterix' chips. SEM images of starch granules showed slower swelling and deformed structure in TPS than in 'Asterix', suggesting that TPS can retain crisp texture longer than 'Asterix'. Although there was no substantial increase of a* and $b^{*}$ value in both potato chips, a lower value of $L^{*}$ and crispiness in TPS, suggests TPS chips lose crispiness and colour within a shorter period of microwave heating than 'Asterix'.
\end{abstract}

Key Words: Colour, crispiness, Solanum tuberosum, TPS

\section{RÉSUMÉ}

L'un des concepts de base du séchage par micro-ondes des frites de pomme de terre (Solanum tuberosum) consiste à obtenir la couleur et la texture souhaitées, en très peu de temps. Dans cette étude, des frites (1 mm d'épaisseur) de variétés des vraies graines de pomme de terre (TPS) («BARI 
TPS-1») et des graines de pommes de terre («Astérix») ont été chauffés pendant 0, 10, 20, 30, 60, 90, 120 , 180 et $300 \mathrm{~s}$ par un four à micro-ondes, et les changements dans les frites ont été analysés physiologiquement et histologiquement pour examiner la pertinence des tubercules TPS en tant que le processus de transformation de pomme de terre. Bien que le croustillant de frites de pomme de terre des deux variétés de pomme de terre ait augmenté de façon continue tout au long du traitement de chauffage, celui de 'BARI TPS-1' a augmenté plus lentement que celui de 'Asterix', indiquant que les frites de TPS sont devenues moins rigides et moelleuses que les chips d'Astérix après le chauffage par micro-ondes. Les images de SEM pour les granules d'amidon ont montré un gonflement plus lent et une structure déformée dans TPS qu'à Astérix, ce qui suggère que TPS peut conserver une texture croustillante plus longtemps qu 'Astérix. Bien qu'il n'y ait pas eu d'augmentation substantielle des valeurs $a *$ et $b *$ dans les deux croustilles, une valeur inférieure de $L *$ et de croustillant dans TPS, suggère que les frites TPS perdent leur croustillant et leur couleur en moins de temps que «Astérix».

Mots Clés: Couleur, croustillant, Solanum tuberosum, TPS

\section{INTRODUCTION}

The properties and composition of potato (Solanum tuberosum) tuber affect the technological processing, yield and quality of the finished product. A large number of potato tubers is processed to make chips, french fries and similar products. An important quality requirement for these tubers is the ability to produce light-coloured, flavourful fried products that are acceptable to consumers. The textural and colour features are the major determinants for suitability of potato to chips (Mendoza et al., 2007), and can be evaluated by sensory and instrumental methodologies.

A conventional drying method involves their prolonged exposure to elevated drying temperatures, which causes substantial deterioration of such quality attributes like colour, nutrient concentration, flavour and texture of food material (Maskan, 2000; Askari et al., 2008). To prevent this quality deterioration, as well as achieve fast and effective thermal processing, a microwave application for food drying has been widely used in recent decades (Cerretani et al., 2009).

One of the most important quality attributes of potato chips is the crispy texture, which is referred as the crispiness (Salvador et al., 2009). During microwave heating, the air pressure rapidly converts the water in potato slices to steam, which expands the tissue and produces the puffy and crispy texture of the chips (Sham et al., 2001).

Another basic concept of microwave drying of potato chips was to achieve the desired chip colour. It permits a shorter drying time and a substantial improvement in the quality of dried materials. Conventional heating causes surface gelatinisation, but microwave heating disrupts the granules due to evaporation of water molecules present in the crystalline region (Karkkainen et al., 2011). Xie et al. (2013) reported heavy deformation, fracturing and collapse of potato starch granule after 20 $\mathrm{s}$ treating of microwave heating at $95{ }^{\circ} \mathrm{C}$. Colour is another important attribute for potato chips.

Microwave drying has the inability to induce browning as it inhibits enzymatic action responsible for browning (Chavan and Chavan, 2010). Joshi et al. (2016) observed that potato chips of 'Kufri Chipsona-2' did not show any sign of enzymatic browning during the whole drying process in the microwave.

Suitable varieties with high-quality seed potatoes are essential for profitable and sustainable potato cultivation (NIVAP, 2011), as well as potato products. As a solution for long storage and low-cost transportation, True Potato Seed or the actual 'Botanical potato seed' (TPS) were piloted to produce good quality seeds or edible tubers. However, there are few studies on the properties of tubers 
produced from TPS as processed potato compares to common potato. The objective of the present study was to evaluate the colour change of potato slice and histological changes of starch granule due to microwave heating at different time variation observed between seed and TPS tubers.

\section{MATERIALS AND METHODS}

Potato tubers from 'BARI TPS-1' (TPS) and from 'Asterix' (seed potato) were obtained from Bangladesh (Fig. 1). Potato samples were of 1 month (25-35 days) after harvest, and non-stored tubers. Fresh weight, volume and specific gravity of all the tubers were measured. Ten tubers per each cultivar were taken for the experiment. Each potato was sliced at $1 \mathrm{~mm}$ thickness using a potato slicer, and used for microwave heating.

Five to six sliced tubers were taken from each cultivar and the slices were heated in a microwave oven for $0,10,20,30,60,90$, 120,180 and $300 \mathrm{~s}$ using one slice for each heating time. The weight of the potato slices was measured following the heating treatment. The potato samples were placed in the same position (center) within the microwave to ensure uniform heating on every potato slice. Tests were conducted to select the conditions required for each treatment. Potato sample weight was taken after microwave treatment.

Potato tuber slices were weighed before and after heat treatments for determination of water loss. Potato chips crispiness was also measured before and after the heat treatments using a Fource Gauge and AD equipped with a $5 \mathrm{~mm}$ triangle plunger.

Instrumental measurement of chip colour before and after drying was performed using a colour meter (NF333, Nippon Denshoku, Saitama, Japan) on the CIELAB scale. The colour of potatoes was measured on 30 slices, selected randomly, and was described by three coordinates in the colour space: $\mathrm{L}^{*}$ (lightness), $a^{*}$ (redness), b* (yellowness).

Three to five sample pieces of approx $5 \mathrm{x}$ $5 \mathrm{~mm}$ were taken from the middle portion (not central) of each treated and untreated potato slice and dipped into $5 \mathrm{ml}$ FAA solution in micro tubes, and kept at ambient temperature at the laboratory of Bioproduction department, Yamagata University, Japan. Then all the sample pieces were prepared for SEM studies after coating Pt by ion coater.

Data collected were subjected to analysis of variance and the differences between cultivars was compared with student's t-test using SPSS software.

\section{RESULTS AND DISCUSSION}

In 'Asterix' potato chips, the moisture loss increased from $3.54,8.56$ to $12.47 \%$ after 10 , 20 and $30 \mathrm{~s}$ of microwave heating, respectively, and continued to increase thereafter. Moisture loss of 'BARI TPS-1' showed a similar tendency, but the values after 10,20 and $30 \mathrm{~s}$ of microwave heating (5.58, 15.14 and $16.84 \%$, respectively) were higher
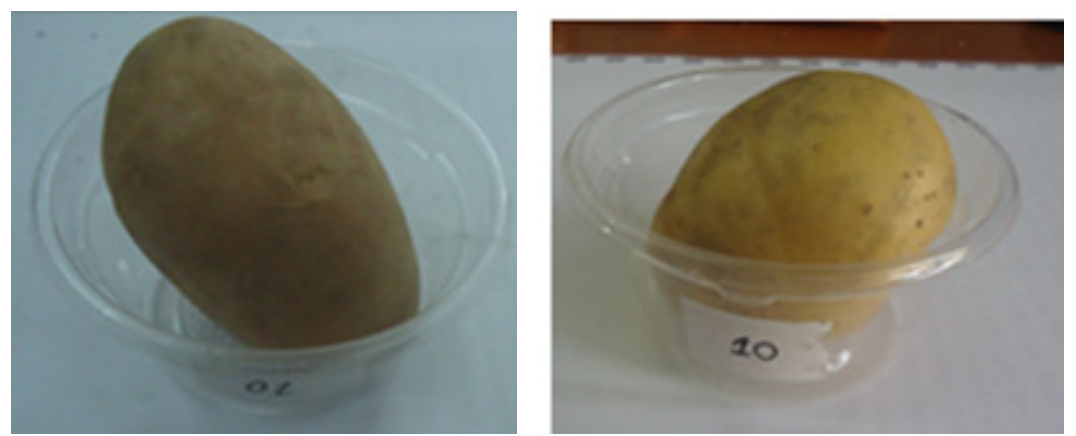

Figure 1. Potato varieties used for microwave heating; BARI TPS-1 (left), Asterix (right). 
than those of 'Asterix' (Fig. 2). Similar increase in moisture loss in potato chips was observed by (Singh et al., 2013) (potato) and (Bai-Ngew et al., 2011) (durian chips). Chua and Chou (2005) reported that the rapid energy absorption by microwaving caused, fast evaporation of water, which results in higher rates of moisture loss. They also observed shortening of drying time by $42 \%$ of carrot chips after 60 to $120 \mathrm{~s}$ of microwave drying at $40^{\circ} \mathrm{C}$ temperature. Comparatively, the higher moisture loss percentage of 'BARI TPS1 ' than that of 'Asterix' after 10, 20 and $30 \mathrm{~s}$ of heating, indicates higher evaporation rate in TPS (Fig. 2).

In 'Asterix', the crispiness increased to 24 after $10 \mathrm{~s}$ of heating, then gradually increased continuously thereafter. The crispiness of 'BARI TPS-1' also showed similar tendency, but the value (16.3) after $10 \mathrm{~s}$ of heating was less than that of 'Asterix' (Fig. 3). Therefore, crispiness of 'Asterix' was significantly higher than that of 'BARI TPS-1' during 0 to $180 \mathrm{~s}$ of heating. The texture of potato chips depends upon the temperature gradient, and the hardness of the tissue or cellular structure (Taiwo et al., 2001; Lewicki and PorzeckaPawlak, 2005). Relatively lower crispiness of 'BARI TPS-1' chips than that of 'Asterix' chips (Fig. 3), indicated a higher requirement of microwave energy to penetrate the tissue during microwaving for the different time period (Yam and Lai, 2004). The changes in thickness, length and width of potato samples during drying, increases linearly with decreasing moisture content (Singh and Kaur, 2009). Rapid water loss may have directly made the deformation and damage of cells and the form of porous structure (Isik et al., 2016). This may explain the increased crispiness of 'Asterix' chips (Contreras et al., 2005).

Representative potato chips from each variety after microwave treatment for the different time periods $(0,10,20,30,60,90$, 120, 180 and $300 \mathrm{~s}$ ) are shown in Figs. 5 - 7. The changes in potato chips from each variety after microwave treatment are summarised in Table 1. Microwave treated potato chips

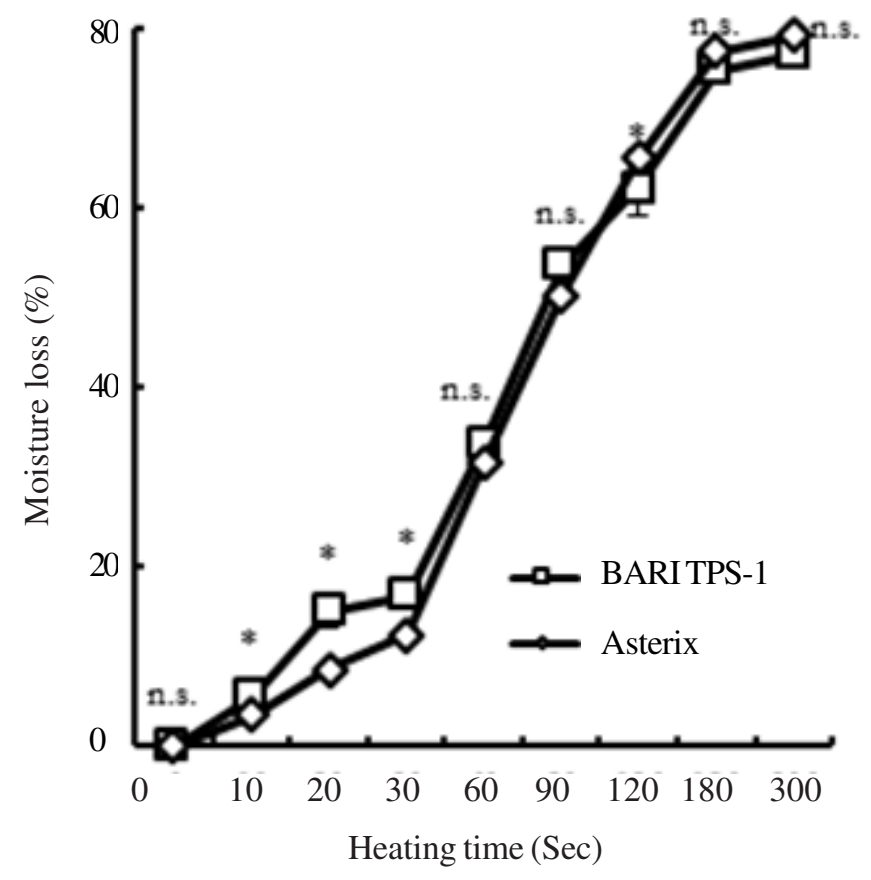

Figure 2. Effect of moisture loss on potato chips as influenced by microwave heating $(n=10 \pm S E)$. * shows significant difference and n.s. shows non-significant difference at $\mathrm{P}<0.05$ by student's t-test. 


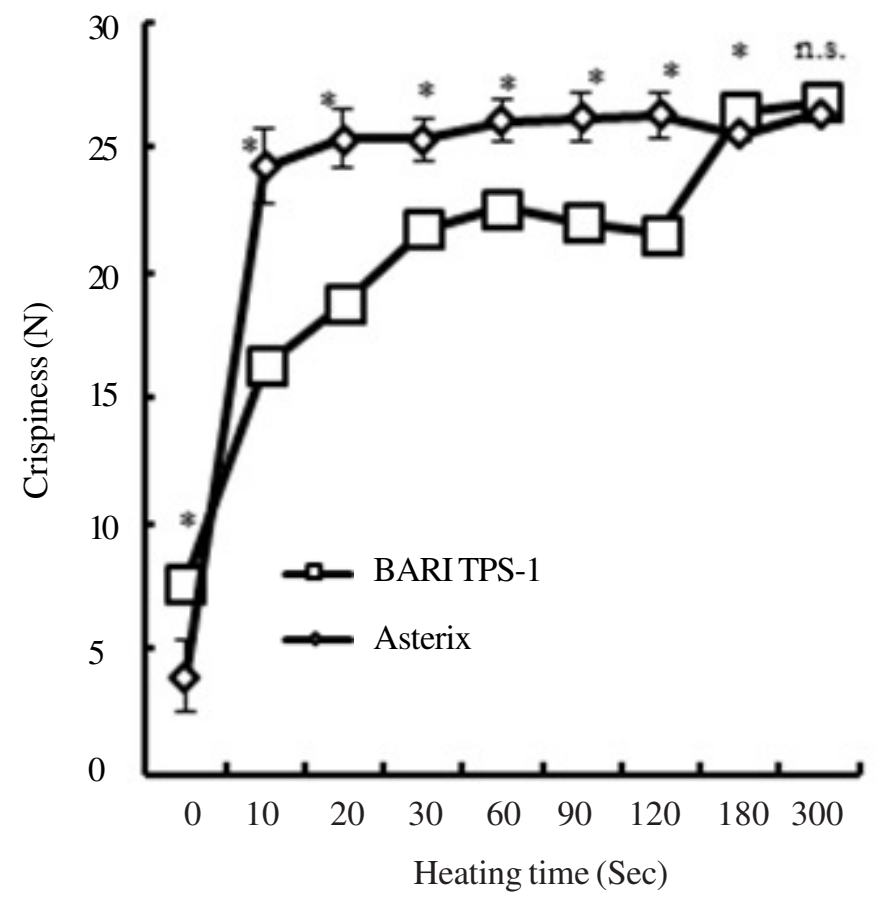

Figure 3. Effect of crispiness on potato chips as influenced by microwave heating $(n=10 \pm S E)$.

* shows significant difference and n.s. shows non-significant difference at $\mathrm{P}<0.05$ by student's t-test.

showed crisped structure and colour change from whitish to brown colour in both varieties.

The cross-sectioned portions of representative potato chips from each variety after microwave treatments for the different time period $(0,10,20,30,60,90,120,180$ and 300s) are shown in Figures 8 and 9. The changes in potato chip structures from each variety after microwave treatments are summarised in Table 2. 'BARI TPS-1' showed faster swelling and deformed structure than 'Asterix'. Asterix' potato chips showed visible browning earlier than TPS, after $180 \mathrm{~s}$ of microwaving (Fig. 7), suggesting high temperature accumulation in the sample (Bondaruk et al., 2007).

Microwave treated potato chips of both varieties showed disintegrated cell wall and shrinkage of starch granules (Figs. 8 and 9) (Liu et al., 2012). Longer microwave heating might have resulted this feature due to the increased compactness of granules, caused by the gelatinisation and retrogradation of starch
(Sadeghi and Shawrang, 2008; Karkkainen et al., 2011). There was evidence of compact and dense granules in both varieties and 'BARI. TPS-1' showed comparatively more compact structure after $90 \mathrm{~s}$ of microwaving (Fig. 9). This might explain the fact that starch granules of TPS may hydrate more rapidly than the local potato starch. This occurred because steam or vapour could not escape quickly enough, leading to internal pressure rise, which ruptured the starch granules and damaged the texture (Wang and $\mathrm{Xi}, 2005$ ). Under increasing duration of microwaving, microwave energy vibrates the water molecules present in the crystalline regions of the starch granules, thereby destroying the lamellar arrangement which destroys granular surfaces (Palav and Seetharaman, 2006).

In 'Asterix', L* started to increase after $10 \mathrm{~s}$ of microwave heating, and continued thereafter in the range of 71 to 77 (Fig. 4). L* of 'BARI TPS-1' showed no significant changes after microwave heating, resulting in 

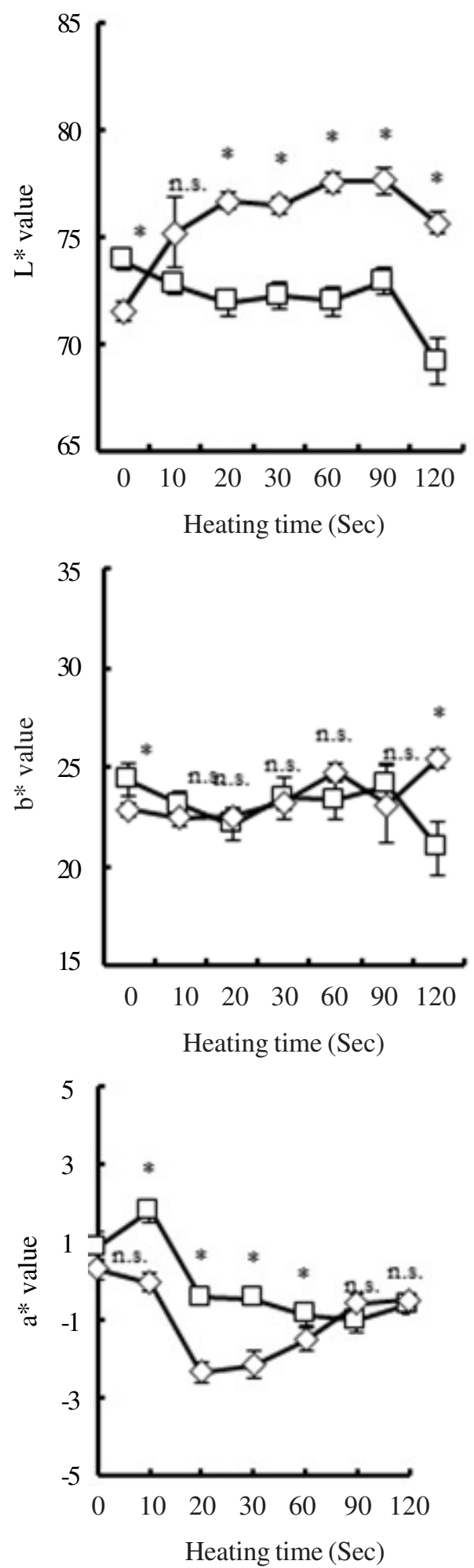

Figure 4. Effect of colour indices on potato chips as influenced by microwave heating $(n=10 \pm S E)$. * shows significant difference and n.s. shows non-significant difference at $\mathrm{P}<0.05$ by student's t-test. 


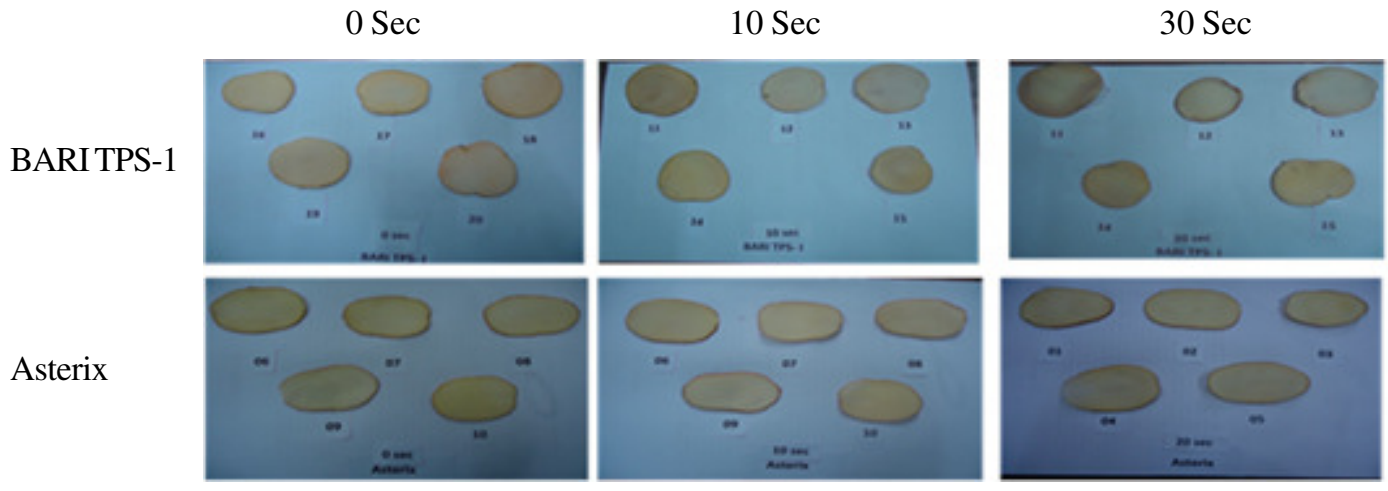

Figure 5. Microwave heated potato chips for 0,10 and $20 \mathrm{sec}$ of two potato varieties.

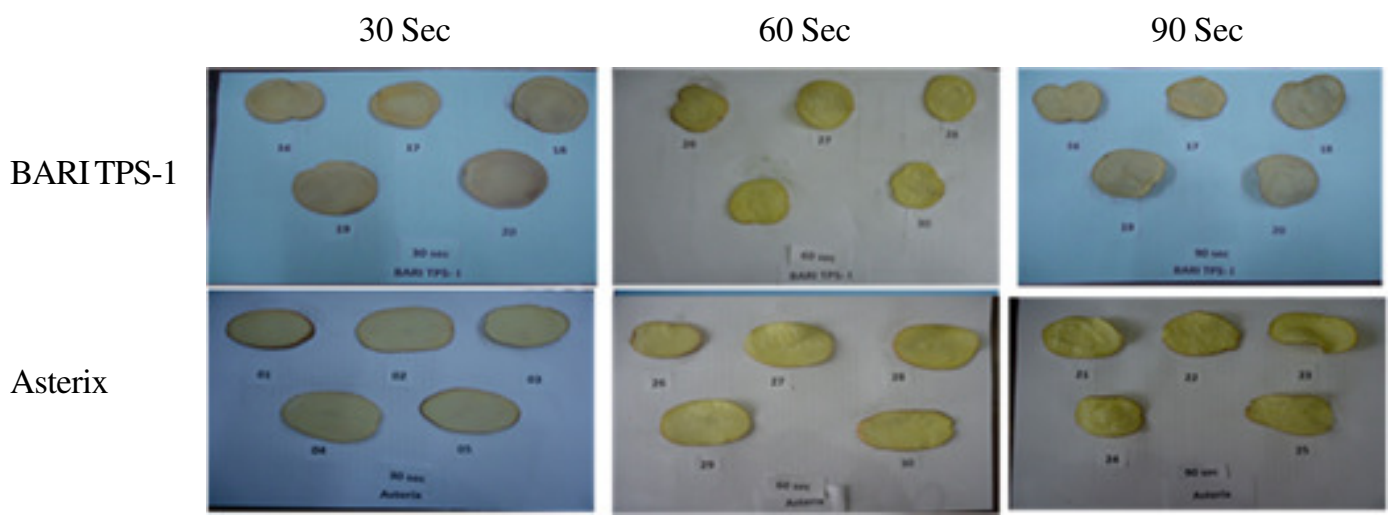

Figure 6. Microwave heated potato chipsfor 30, 60 and $90 \mathrm{sec}$ of two potato varieties.

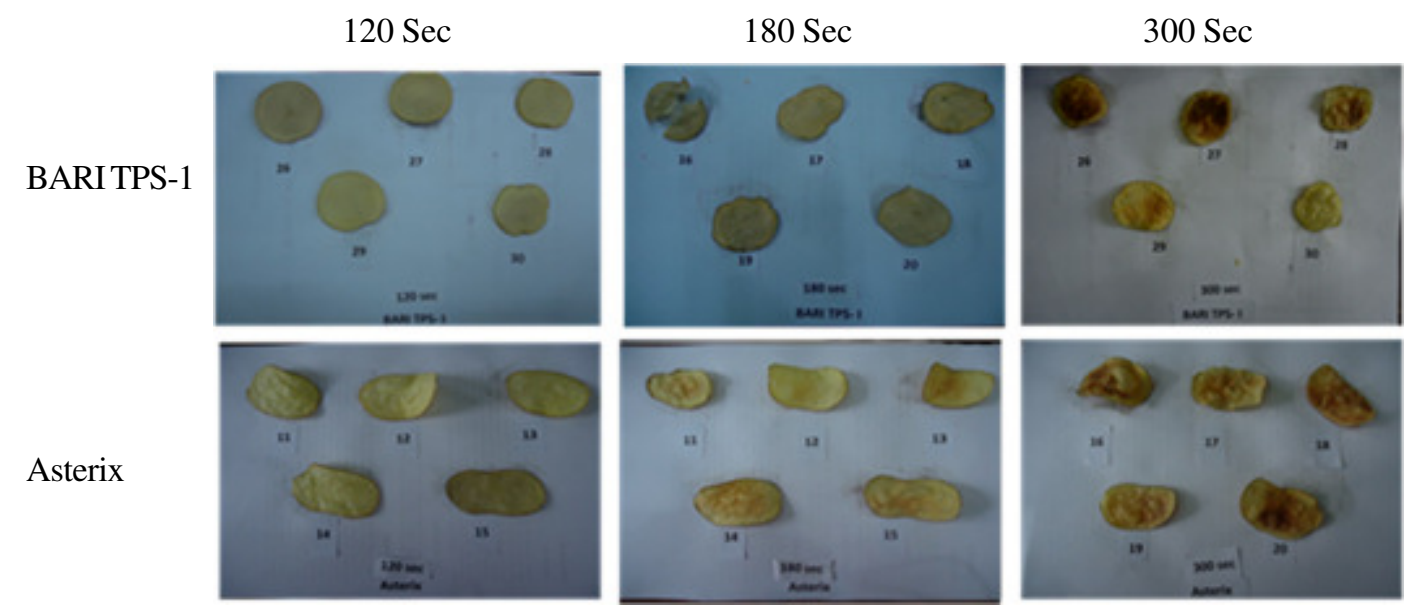

Figure 7. Microwave heated potato chipsfor 120, 180and $300 \mathrm{sec}$ of two potato varieties. 
TABLE 1. Changes of potato chips after microwave treatment of two potato varieties

\begin{tabular}{|c|c|c|c|c|c|c|c|c|c|}
\hline \multirow[t]{2}{*}{ Variety } & \multicolumn{9}{|c|}{ Heating time (sec) } \\
\hline & 0 & 10 & 20 & 30 & 60 & 90 & 120 & 180 & 300 \\
\hline BARITPS-1 & $\begin{array}{l}\text { Uniform } \\
\text { sized slices }\end{array}$ & $\begin{array}{l}\text { No visible } \\
\text { colour } \\
\text { change }\end{array}$ & $\begin{array}{l}\text { Slightly } \\
\text { dried texture } \\
\text { at edge, whitish }\end{array}$ & $\begin{array}{l}\text { Some chips } \\
\text { are yellowish }\end{array}$ & $\begin{array}{l}\text { Yellowish } \\
\text { slices }\end{array}$ & $\begin{array}{l}\text { Yellowish, } \\
\text { dried texture }\end{array}$ & $\begin{array}{l}\text { Crispness } \\
\text { not visible }\end{array}$ & $\begin{array}{l}\text { Fluffy, } \\
\text { porous } \\
\text { structure, } \\
\text { less browning } \\
\text { than Asterix }\end{array}$ & $\begin{array}{l}\text { Mostly } \\
\text { browning } \\
\text { appeared }\end{array}$ \\
\hline Asterix & $\begin{array}{l}\text { Uniform } \\
\text { sized slices }\end{array}$ & $\begin{array}{l}\text { No visible } \\
\text { colour } \\
\text { change }\end{array}$ & $\begin{array}{l}\text { Whitish } \\
\text { appearance }\end{array}$ & $\begin{array}{l}\text { Whitish } \\
\text { appearance }\end{array}$ & $\begin{array}{l}\text { Dried } \\
\text { textureat } \\
\text { edge, } \\
\text { whitish }\end{array}$ & $\begin{array}{l}\text { Fluffy,porous } \\
\text { structure } \\
\text { visible }\end{array}$ & $\begin{array}{l}\text { Fluffy, porous, } \\
\text { structure } \\
\text { visible }\end{array}$ & $\begin{array}{l}\text { Browning } \\
\text { visible }\end{array}$ & $\begin{array}{l}\text { Less } \\
\text { browning } \\
\text { than TPS }\end{array}$ \\
\hline
\end{tabular}


TABLE 2. Changes of potato chip structures after microwave treatment of two potato varieties

\begin{tabular}{|c|c|c|c|c|c|c|c|c|c|}
\hline \multirow[t]{2}{*}{ Variety } & \multicolumn{8}{|c|}{ Heating time (sec) } & \multirow[b]{2}{*}{300} \\
\hline & 0 & 10 & 20 & 30 & 60 & 90 & 120 & 180 & \\
\hline BARI TPS-1 & $\begin{array}{l}\text { Small } \\
\text { individual } \\
\text { granules }\end{array}$ & $\begin{array}{l}\text { Granules } \\
\text { started to } \\
\text { swell }\end{array}$ & $\begin{array}{l}\text { Small to } \\
\text { medium } \\
\text { swollen } \\
\text { granules }\end{array}$ & $\begin{array}{l}\text { Cell wall } \\
\text { ruptured, } \\
\text { swollen, } \\
\text { medium to } \\
\text { large } \\
\text { clumped } \\
\text { granules }\end{array}$ & $\begin{array}{l}\text { Cell wall } \\
\text { ruptured, } \\
\text { small to medium } \\
\text { swollen granules }\end{array}$ & $\begin{array}{l}\text { Swollen } \\
\text { clustered } \\
\text { granules }\end{array}$ & $\begin{array}{l}\text { Cell wall } \\
\text { ruptured, } \\
\text { clumped } \\
\text { region }\end{array}$ & $\begin{array}{l}\text { Irregular, } \\
\text { swollen } \\
\text { granule visible }\end{array}$ & $\begin{array}{l}\text { Ruptured } \\
\text { from side, } \\
\text { center } \\
\text { depression, } \\
\text { mostly } \\
\text { deformed }\end{array}$ \\
\hline Asterix & $\begin{array}{l}\text { Small } \\
\text { individual } \\
\text { granules }\end{array}$ & $\begin{array}{l}\text { Mostly } \\
\text { individual } \\
\text { small } \\
\text { granules }\end{array}$ & $\begin{array}{l}\text { Small to } \\
\text { medium } \\
\text { swollen } \\
\text { granules }\end{array}$ & $\begin{array}{l}\text { Medium to } \\
\text { large swollen } \\
\text { granules }\end{array}$ & $\begin{array}{l}\text { Cell wall } \\
\text { ruptured, } \\
\text { small to medium } \\
\text { clumped granules }\end{array}$ & $\begin{array}{l}\text { Large, } \\
\text { swollen, } \\
\text { cell cluster }\end{array}$ & $\begin{array}{l}\text { Ruptured, } \\
\text { clumped } \\
\text { region }\end{array}$ & $\begin{array}{l}\text { Ruptured, } \\
\text { clumped } \\
\text { region }\end{array}$ & $\begin{array}{l}\text { Gelatinised, } \\
\text { small } \\
\text { intercellular } \\
\text { space }\end{array}$ \\
\hline
\end{tabular}




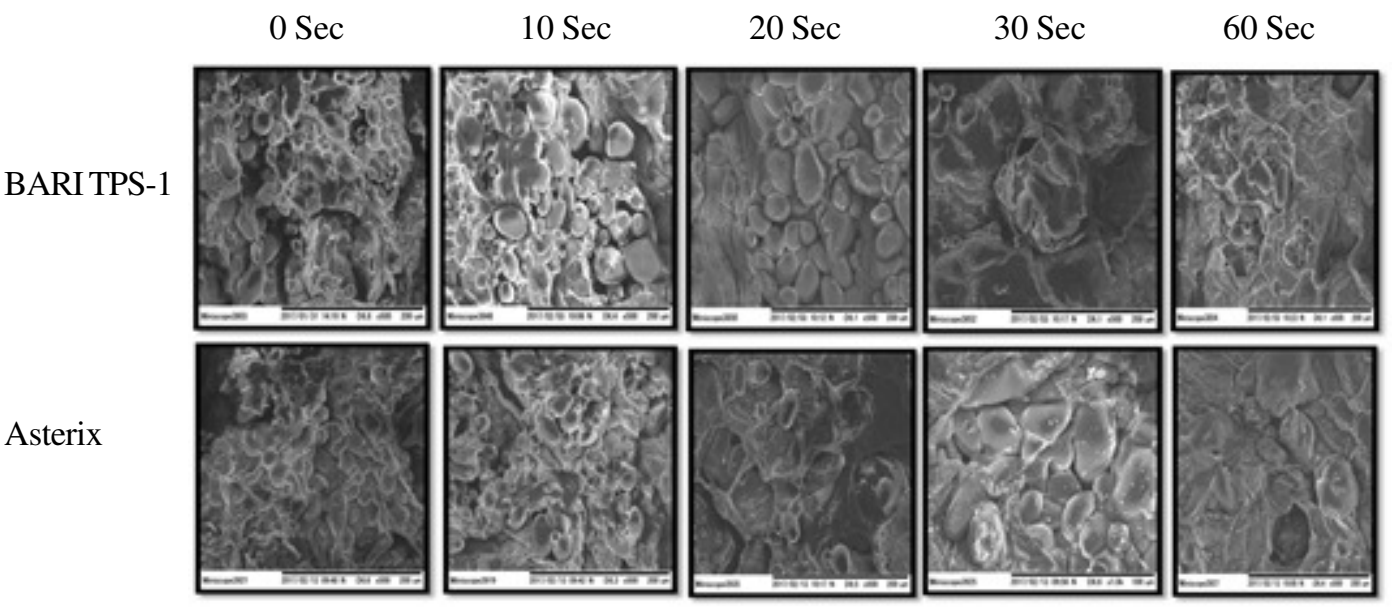

Figure 8. SEM images of the cross sections of microwave heated potato chips for $0,10,2030$ and 60 sec of two potato varieties.

$90 \mathrm{Sec}$
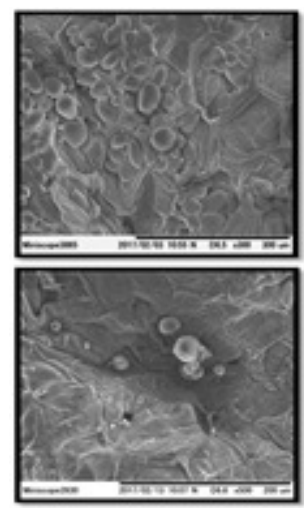

$120 \mathrm{Sec}$
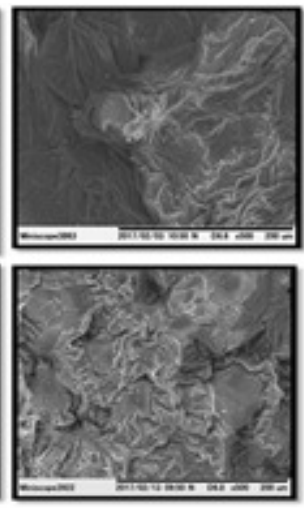

$180 \mathrm{Sec}$
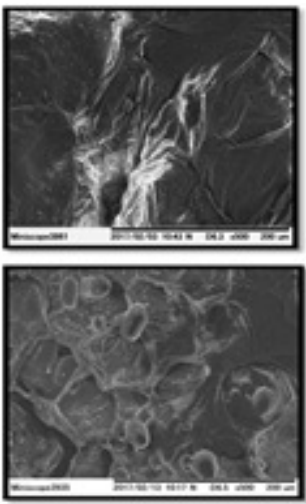

$300 \mathrm{Sec}$

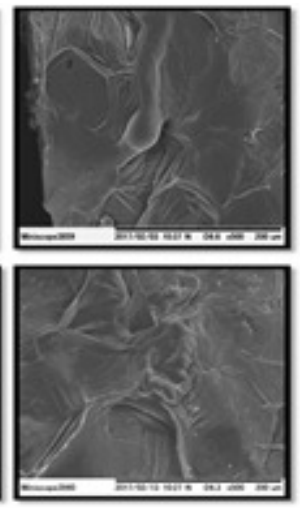

Figure 9. SEM images of the cross sections of microwave heated potato chips for 90, 120, 180 and 300 sec of two potato varieties.

a significant difference between the varieties during 20 to $90 \mathrm{~s}$ of heating. Although the $\mathrm{b}^{*}$ of 'BARI TPS-1' did not show significant changes after microwave heating, the values decreased (20) after $120 \mathrm{~s}$ of heating (Fig. 4). b* of 'Asterix' showed the same tendency, but the value after $120 \mathrm{~s}$ of microwave heating was higher (25) than that of 'BARI TPS-1'. Therefore, $b^{*}$ of 'Asterix' was significantly higher than that of 'BARI TPS-1' after $120 \mathrm{~s}$ of microwave heating. In 'BARI TPS-1' chips, $\mathrm{a}^{*}$ reached to the highest value of 1.80 after $10 \mathrm{~s}$ of heating then decreased continuously thereafter (Fig. 4). a* of 'Asterix' after $10 \mathrm{~s}$ of heating was much lower $(-0.04)$ than that of 'BARI TPS-1' and decreased rapidly, thereafter, resulting in a significant difference between the two varieties during 10, 20, 30 and $60 \mathrm{~s}$ of heating.

No substantial increase of $a^{*}$ and $b^{*}$ up to $120 \mathrm{~s}$ of microwaving indicates no enzymatic browning reaction occurred during heating in both varieties (Figs. 4). This can be explained by fast inactivation of enzymes due to the sharp rise in temperature of samples, and by the relatively low temperature of the samples 
during microwaving which was not high enough to initiate the Maillard reactions (Bondaruk et al., 2007). The results also showed that a higher drying rate may cause comparatively higher lightless ( $\left.\mathrm{L}^{*}\right)$ in Asterix' than TPS chips (Fig. 4).

\section{CONCLUSION}

True Potato Seed (TPS) chips can retain the crispiness and colour longer than that of 'Asterix' after microwave heating. Although the crispiness and lightness were comparatively lower than seed potato 'Asterix', 'BARI TPS1 ' chips have the advantage of slower Maillard reaction and longer crisp structure. Therefore, TPS potato can also be used for chip production. Although the crispiness and lightness of TPS chips was not as high as the seed potato chips, they were still acceptable as potato chips.

\section{REFERENCES}

Askari, G., Emam-Djomeh, Z. and Mousavi, S. 2008. Investigation of the Effects of Microwave Treatment on the Optical Properties of Apple Slices during Drying. Drying Technology 26(11): 1362-1368. DOI: 10.1080/07373930802333502.

Bai-Ngew, S., Therdthai, N. and Dhamvithee, P. 2011. Characterization of microwave vacuum-dried durian chips. Journal of Food Engineering 104:114 - 122. DOI: 10.1016/j.jfoodeng.2010.12.003.

Bondaruk, J., Markowski, M. and Blaszczak, W. 2007. Effect of drying conditions on the quality of vaccum-microwave dried potato cubes. Journal of Food Engineering $81: 306$ - 312. DOI: 10.1016/ j.jfoodeng.2006.10.028.

Cerretani. L., Bendini. A., Rodrigez-Estrada, M.T. and Vittadini, E. 2009. Microwave heating of different commercial categories of olive oil: part 1. Effect on chemical oxidative stability indices and phenolic compounds. Food Chemistry 115:1381-
1388. DOI: 10.1016/j.foodchem.2009. 01.060.

Chavan, R.S. and Chavan, S.R. 2010. Microwave baking in food industry: A Review. International Journal of Dairy Science 5:113-127. DOI: 10.3923/ ijds.2010.113.127.

Chua, K.J. and Chou, S.K. 2005. New Hybrid Drying Technologies. In: Emerging Technologies for Food Processing, Sun DW (Ed), Elsevier Academic Press, California, pp. 536-551. DOI: 10.1016/ B978-012676757-5/50022-0.

Contreras, C., Martín, M.E., MartínezNavarrete, N. and Chiralt, A. 2005. Effect of vacuum impregnation and microwave application on structural changes which occurred during air-drying of apple. LWTJ. Food Science and Technology 38:471 477. DOI: 10.1016/j.lwt.2004.07.017.

Isik, B., Sahin, S. and Sumnu, G. 2016. Pore development, oil and moisture distribution in crust and core regions of potatoes during frying. Food and Bioprocess Technology 10:1653 - 1660. DOI: 10.1007/s11947016-1748-4.

Joshi, A., Rudra, S.G., Sagar, V.R., Raigond, P., Dutt, S., Singh, B. and Singh, B.P. 2016. Development of low fat potato chips through microwave processing. Journal of Food Science and Technology 53:3296 3303. DOI: 10.1007/s13197-016-2304-y.

Karkkainen, J., Lappalainen, K., Joensuu, P. and Lajunen, M. 2011. HPLC-ELSD analysis of six starch species heat-dispersed in [BMIM] $\mathrm{Cl}$ ionic liquid. Carbohydrate Polymers 84:509 - 516. DOI: 10.1016/ j.carbpol.2010.12.011.

Lewicki, P.P. and Porzecka-Pawlak, R. 2005. Effect of osmotic dewatering on apple tissue structure. Journal of Food Engineering 65:519-525. DOI: 10.1016/ j.jfoodeng.2004.02.032.

Liu, J., Ming, J., Li, W. and Zhao, G. 2012. Synthesis, characterisation and in vitro digestibility of carboxymethyl potato starch rapidly prepared with microwave- 
assistance. Food Chemistry 133:1196 1205. DOI: 10.1016/j.foodchem.2011. 05.061 .

Maskan, M. 2000. Microwave/air and microwave finish drying of banana. Journal of Food Engineering 44:71 - 78. DOI: 10.1016/S0260-8774(99)00167-3.

Mendoza, F., Dejmek, P. and Aguilera, J.M. 2007. Colour and image texture analysis in classification of commercial potato chips. Food Research International 40:1146 1154. DOI: $\quad 10.1016 /$ j.foodres.2007.06.014.

NIVAP. 2011. Netherlands catalogue of potato varieties. Peeten HMG, Folkertsma S, Schipper JK, Baarveld HR, Klein S (eds). NIVAP, Den Haag, Netherlands. $<$ www.nivap.nl>

Palav, T. and Seetharaman, K. 2006. Mechanism of starch gelatinization and polymerleaching during microwave heating. Carbohydrate Polymers 65:364 370. DOI: 10.1016/j.carbpol.2006.01.024.

Sadeghi, A.A. and Shawrang, P. 2008. Effects of microwave irradiation on ruminal dry matter, protein and starch degradation characteristics of barley grain. Animal Feed Science Technology 141:184-194. DOI: 10.1016/j.anifeedsci.2007.05.034.

Salvador, A., Varela, P., Sanz, T. and Fiszman, S.M. 2009. Understanding potato chips crispy texture by simultaneous fracture and acoustic measurements, and sensory analysis. LWT-Food Science and Technology 42: 763-767. DOI:10.1016/ j.lwt.2008.09.016.

Sham, P.W.Y., Scaman, C.H. and Durance, T.D. 2001. Texture of vacuum microwave dehydrated apple chips as affected by calcium pretreatment, vacuum level and apple variety. Journal of Food Science 66 (9): 1341-1347. DOI: $10.1111 / \mathrm{j} .1365-$ 2621.2001.tb15212.x

Singh, J. and Kaur, L. 2009. Advances in Potato Chemistry and Technology, 1 st ed. Academic Press: Cambridge, MA, USA, pp. 273-318. DOI: 10.1016/B978-0-12374349-7.X0001-3.

Singh, A., Nair, G.R., Rahimi, J., Gariepy, Y. and Raghavan, V. 2013. Effect of Static High Electric Field Pre-Treatment on Microwave-Assisted Drying of Potato Slices. Drying Technology 31(16): 19601968. DOI: $10.1080 /$ 07373937.2013.805142.

Taiwo, K.A., Angersbach, A., Ade-Omowaye, B.I.O. and Knorr, D. 2001. Effect of pretreatments on the diffusion kinetics and some quality parameters of osmotically dehyderated apple slices. Journal of Agricultural and Food Chemistry 49: 28042811. DOI: $10.1021 /$ jf0009798.

Wang, J. and Xi, Y.S. 2005. Drying characteristics and drying quality of carrot using a two-stage microwave process. Food Engineering 68: 505-511. DOI: 10.1016/j.jfoodeng.2004.06.027.

Xie, Y., Yan, M., Yuan, S., Sun, S. and Huo, Q. 2013. Effect of microwave treatment on the physicochemical properties of potato starch granules. Chemistry Central Journal 7:113. DOI: 10.1186/1752-153X-7-113.

Yam, K.L. and Lai, C.C. 2004. (Eds).: Microwavable frozen food or meals. In: Handbook of Frozen Foods. Marrell, K.D., Hui, Y.H., W-K. Nip, W-K., Lim, M.H., Legarreta, I.G. and Cornillon, P. (Eds.), pp. 581-593. CRC Press, USA. DOI: 10.1201/ b15995-127. 